\title{
Ny sikkerhedstrekant mellem Sydkorea, Kina og Japan
}

Thomas Høy Davidsen

\section{Nye strategiske overvejelser i Tokyo, Seoul og Bei-

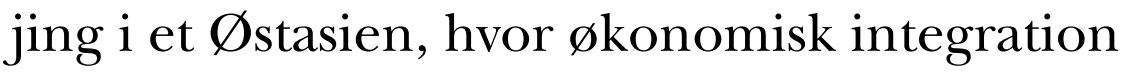 skaber større tillid, mens det stille våbenkapløb mellem rivalerne Japan og Kina tager til}

De kom igen i år, Japans ultranationalister, for at ære de soldater, der er faldet i krig, og dermed også de mange, der faldt i Anden Verdenskrig. Hvert år den 15. august drager de i hobetal til shintohelligdommen Yasukuni midt i Tokyo for at hylde en del af det tyvende århundredes historie, som både Kina og Korea finder dybt anstødelig.

De samles uden for tempelområdet, hvor de med skrig og råb fordømmer, hvad de kalder Vestens 'revisionistiske' tolkning af krigens historie - Japan drog nemlig ikke i krig, hævder de, for at underlægge sig Asien, men for at drive de vestlige kolonimagter ud af kontinentet, og de japanske tropper begik heller ingen af de utallige krigsforbrydelser, som den kejserlige hær huskes for i dag.

Inden for i templets inderste hal- ler er der stille. Her samles de mere konservative medlemmer af landets elite til en række højtidelige mindeceremonier, der har til formål ikke at glorificere krigen, men at mindes de, der faldt for landet, og med deres offer gjorde Japan til den nation, den er i dag. Mange af Japans mest magtfulde politikere har også deltaget, som for eksempel den kontroversielle premierminister Junichiro Koizumi, der på trods af voldsom kritik fra de asiatiske naboer deltog $\mathrm{i}$ templets højtideligheder hvert år i sin regeringsperiode 2001-2006.

Men ikke i år. I år har politikerne holdt sig væk.

"Den politiske opbakning til højtidelighederne i Yasukuni er dalende og har været det i årevis", forklarer en af Japans højst rangerende shintopræster mig efter ceremonierne. "I dag kom hverken premierministe- 
ren eller nogle af hans ministre. Det er en stor skam, for selvom jeg forstår, at sådanne besøg er meget kontroversielle, og jeg kun ønsker fred i Asien, så har vi i Japan ret til at være stolte over vores historie, og desuden er vi forpligtigede til at vise respekt over for vores forfædre. Det må andre lande forstå." For ham og mange andre konservative japanere kædes Yasukuni ikke kun sammen med mindet om krigen, men også med hele landets kulturelle selvforståelse. Det er derfor sigende, når klagerne fra den elite, som Japans toppolitikere gør klogt i at holde sig gode venner med, ignoreres.

\section{Spillet om Yasukuni}

Ingen premierminister har nemlig siden Koizumi vovet at tage til Yasukuni den 15. august, og den manglende politiske opbakning er et udtryk for, at magtbalancen i Nordøstasien er ved at ændre sig. Denne magtbalance blev født af den kolde krig, da USA havde brug for Japan som allieret i kampen mod USSR og kommunismen, og da nabolande som Kina og Sydkorea sakkede langt bagefter økonomisk, kunne Japan i kraft af sin egen udvikling og nære forhold til USA hurtigt indtage pladsen som i hvert fald det kapitalistiske Asiens leder.

Japan har holdt sig på førstepladsen længe, men med den kolde krigs afslutning, Kinas monumentale vækst og Japans egen stagnation er Nordøstasien nu i færd med en langsom og omfattende transformation, og Japan har ikke længere råd til at støde sine naboer fra sig, hvis landet vil beholde sin nuværende indflydelse.

Japan har indset, at det ikke er uden omkostninger konstant at fornærme sine naboer, og da Japan ønsker at forblive blandt regionens stormagter, skal den manglende politiske opbakning til Yasukuni ses som en brik i et kompliceret spil, der omhandler økonomi, internationale handelsforbindelser, militære forhold og territorialstridigheder. Det er et spil, der er påvirket af historiens lange skygge, og som vil udfolde sig i løbet af de næste årtier, men som foregår inden for visse rammer, og et kendskab til disse er nødvendig for at forstå strømningerne i Østasien under den nuværende forvandling fra fattigdom og diktatur til en af verdens mest dynamiske regioner.

I 2010 overhalede Kina officielt Japan og blev verdens næststørste økonomi. Det er i sig selv ingen større nyhed, for selv hvis Japan havde formået at revitalisere sin økonomi efter krakket i begyndelsen af 1990'erne, gør Kinas enorme størrelse, at det kun var et spørgsmål om tid, før Japan rykkede et trin ned ad rangstigen, og Japans bruttonationalprodukt pr. indbygger er stadig langt højere end dets enorme nabo - men Kinas vækst og selvsikre fremfærd i Asien gør, at Japan nu må genoverveje sin sikkerhedspolitik. 


\section{Ny sikkerhedstrekant}

Det kan betyde, at landet rykker tættere på lillebror-rivalen Sydkorea, der også selv i de sidste ti år har ændret sin sikkerhedsstrategi i takt med Asiens udvikling, og en ny sikkerhedstrekant mellem Sydkorea, Kina og Japan er i dag ved at finde sin udformning. Skal trekanten for alvor stabiliseres, må Japan og Sydkorea nærme sig hinanden, hvilket betyder, at de må afslutte deres kontrovers over Japans manglende undskyldning for landets krigsforbrydelser. Det er ikke nemt, for det er ikke kun et spørgsmål om, at Japan endelig ser sin fortid i øjnene, men at begge lande ændrer på deres selvforståelse gennem de sidste 60 år.

Yasukuni, den store shintohelligdom, spiller en central rolle i den japanske stat, der blev skabt ved Meiji revolutionen i 1868, hvor samuraierne mistede magten. Det var dengang kejseren blev hentet fra Kyoto til Tokyo for at give legitimitet til sejrherrerne. Kejseren blev et symbol for det japanske folk og dets historie. Logikken var simpel - Japan er et bjergrigt land og har derfor socialt og historisk været stærkt fragmenteret, selv i de perioder, hvor det lykkedes diverse samuraiklaner at underlægge sig hele nationen.

Hvis Japan skulle blive en moderne, industrialiseret nation på lige fod med Vesten, ville det kræve en ny form for nationalfølelse, og kejsersymbolikken med dens hellige blodlinje, der strakte sig tilbage gennem århundrederne til Japans mytiske fortid, var det helt særlige, der skulle til for at kunne skabe en ny og forenet japansk selvforståelse.

Kejserens person og kulturelle symbolværdi blev aldrig diskuteret efter Anden Verdenskrigs afslutning, og den manglende debat har resulteret $i$, at hans symbolik stadig udgør en af hjørnestenene i de konservative dele af den japanske psyke - Yasukuni udgør en anden.

Templet fik sit navn i 1879 og fungerede dengang som nu som mindelund for de japanske soldater, der er faldet i landets mange krige siden moderniseringen, men det er samtidig også kejserens tempel. I enhver fremtidig offentlig debat om helligdommen, der måtte komme i Japan, vil det derfor være svært at undgå også at tale om den kejserinstitution, i hvis navn de omtalte soldater gav deres liv, og da kejserinstitutionen stadig udgør landets største tabuemne, er en sådan bred debat ikke sandsynlig.

Da den amerikanske overkommando i Tokyo efter krigen ikke mente, at japanerne ville kunne acceptere besættelsesmyndighederne, hvis den afsatte kejseren, valgte de ikke at stille ham for en krigsforbryderdomstol. Det umuliggjorde hurtigt enhver debat ikke kun om kejserens egentlige rolle i krigen, men også om det japanske samfund under krigen i alt andet end de bredeste penselstrøg. 
Den japanske domstols arbejde var nemlig langt mindre gennemgribende end i Europa - kun 0,29 pct. af befolkningen blev dømt og forment adgang til offentlige stillinger mod 2,5 pct. i Tyskland, og mange af de dømte vendte alligevel hurtigt tilbage i toppen af Japans politik og erhvervsliv.

\section{Tabu i Sydkorea}

Sydkorea har lignende problemer, for ligesom det i Tokyo blev svært at diskutere landets rolle i annekteringen af Korea, blev det i Sydkorea svært at debattere landets rolle under besættelsen. I Sydkorea er historien om de mange sydkoreanske kollaboratører, der gjorde japanernes overherredømme muligt, stadig tabubelagt, ofte af lignende grunde som i Japan, og ligesom i Japan har det betydet, at en egentlig debat om landets fortid er vanskelig. At mange i den sydkoreanske elite samarbejdede med japanerne - ved udgangen af 1920'erne, to årtier efter Japans annektering af landet, talte mange i overklassen endda japansk i hjemmet - undskylder på ingen måde Japans brutalisering af store dele af den koreanske befolkning. Men det betyder, at det var i den samme overklasses interesse ikke at debattere koloniseringens mange pinlige detaljer efter Japans overgivelse.

Desuden blev Sydkorea hurtigt omdannet til et nyt militærdiktatur under den amerikansk-indsatte Syngman Rhee, der var så upopulær, at den eneste måde, han kunne vinde indflydelse på, var ved at bestikke de dele af det politiske apparat, der havde kollaboreret under krigen. Ikke overraskende satte han derfor også med magt en stopper for enhver officiel, retslig undersøgelse af kollaboratørernes rolle.

Sydkorea blev efterfølgende regeret af diverse diktatoriske kliker med hjælp fra et statsligt bureaukrati, hvis synder under besættelsen kun blev forværret af årtiers militærstyre. Det er en arv, som landet stadig har svært ved at se i øjnene - således lød der fra dele af den sydkoreanske elite i 2007 et ramaskrig ved tanken $\mathrm{om}$, at navnene på dommere og advokater, der havde arbejdet for tidligere militærregimer, muligvis ville blive offentliggjort.

Rollen som offer for Japans kolonisering er blevet en del af den moderne koreanske selvforståelse. Dermed giver Sydkoreas manglende accept af de mange officielle undskyldninger, Japan igennem de sidste årtier er kommet med, også mere mening, for så længe den japanske undskyldning ikke tages til efterretning, er illusionen om, at Sydkorea udelukkende var offer, langt lettere at opretholde.

Ikke desto mindre forsøger begge lande at lægge fortiden bag sig, og den seneste officielle undskyldning fra Japan kom i år den 15. august, da premierminister Naoto Kan be- 
sluttede at bruge årsdagen for overgivelsen som anledning til at forbedre de koreanske forbindelser.

Japan og Sydkorea har i de seneste år således bevæget sig tættere på hinanden politisk og gennem en konstant voksende samhandel - selv under premierminister Koizumis kontroversielle regeringsperiode.

I de sidste ti år er handlen mellem de to lande fordoblet, og i årene 2004-2008 voksede den japanske eksport til Sydkorea med hele 22 pct., på trods af voldsomme krav om boykot. Sydkorea var i 2008 verdens største importør af japansk jern og stål og den tredjestørste af japanskfremstillede halvledere, der bruges til produktion af elektroniske produkter som computere og fjernsyn, hvor sydkoreanske firmaer nu er blandt de førende virksomheder i verden. Japansk musik, mode og popkultur er stadig populært i Sydkorea, ligesom sydkoreansk TV er det i Japan, og både Japan, Sydkorea og Kina arbejder nu på en større frihandelsaftale, der skal binde økonomierne endnu tættere sammen.

\section{Ud af krigens skygge}

Denne vilje til at komme ud fra krigens skygge påvirker også forholdet til Kina, idet alle tre lande er store eksportnationer og derfor har brug for, at det politiske klima i Østasien forbliver så udramatisk som muligt. Kinas enorme vækst er i høj grad baseret på den globalisering af verdens produktionskæder, hvori Kinas lavteknologiske industrielle komponenter kan sælges videre til mere avancerede økonomier som den japanske, der bruger komponenterne i sin egen højteknologiske industri.

Allerede i 2002 var Japan derfor også Kinas største udenlandske investor, samme år, som den japanskkinesiske handel oversteg et hundrede milliarder dollar. Tilbage i midten af 1990'erne blev hele 25 pct. af de kinesiske infrastrukturprojekter finansieret fra Tokyo, og i 2007 overtog Kina derfor ikke overraskende også USA's plads som Japans førende handelspartner.

Den nuværende vækst i samhandlen skyldes dog i høj grad den japanske import af kinesiske varer - $\mathrm{i}$ 2009 var 50 pct. af al japansk import fra Kina - og den japanske eksport til USA repræsenterer stadig et større pengemæssigt beløb, fordi den kinesiske middelklasse ikke endnu har samme købekraft som amerikanerne.

Kina har nemlig, på trods af sin fænomenale vækst, ikke kunnet skabe et middelklassesamfund som i Vesten, for landet har ikke formået at skabe en generel vækst i levestandarden på tværs af befolkningen, der modsvarer den årlige vækst $\mathrm{i}$ bruttonationalproduktet - en vækst som regimet på sigt må basere størstedelen af sin legitimitet på.

Det er især områderne langt fra kysterne, der ikke har fået del i udviklingen, og historisk set er det net- 
op konflikter mellem landets fattige indland og de rige kystområder, der har dannet grundlag for mange af Kinas borgerkrige. For at undgå at alvorlige spændinger opstår, må Beijing dermed sørge for, at den økonomiske fremmarch fortsætter, en fremmarch, der er dybt afhængig af eksporten. Derfor er Kina ikke interesseret $i$ at have store kontroverser med rivalen Japan, som den på trods af handelsforbindelserne stadig kæmper med om indflydelse i Østasien.

Beijing har dog tilladt anti-japanske demonstrationer, som fandt sted i 2005 i flere kinesiske storbyer, men de fik ikke lov at kamme over, idet et sådant nationalistisk raseri over fremmede nationers fremfærd flere gange i kinesisk historie er blevet vendt til vrede mod centralmagten. Samtidig er Kina afhængig af sine gode forbindelser til Japan, hvilket kom særligt til udtryk efter tidligere premierminister Jiang Zemins besøg i landet i 1998 i kølvandet på Sydkoreas præsident Kim Dae-jungs japanske statsbesøg.

Kim Dae-jungs rejse var kulminationen på en lang række forhandlinger mellem de sydkoreanske og japanske udenrigsministerier om muligheden for en klar, skriftlig undskyldning for Japans besættelse, som Kim Dae-jung kunne tage med sig tilbage som retfærdiggørelse af mødet med japanerne - et krav, japanerne indvilligede i på den betingelse, at Sydkorea til gengæld lovede al- drig igen at bringe mindet om krigen op.

Kim Dae-jung fik sin undskyldning, og selve turen rundt i Japan blev en strålende succes, der var med til at lægge grunden for de nu blomstrende handelsforbindelser.

\section{Strid om øer}

Efter nyheden om Kim Dae-jungs besøg ville Jiang Zemin også have samme undskyldning, men der var ikke tid til at indgå i samme lange og møjsommelige forhandlinger. Jiang Zemin blev rådet til at udsætte mødet, men tog alligevel til Japan, hvor han tordnede løs om landets mange forbrydelser. Undskyldningen kom han ingen vegne med, og Jiang Zemin måtte i stedet forlade et Japan, der nu var langt mere uvenligt og mistænksomt end før. Der gik derfor ikke længe, før Kina reviderede sin Japanpolitik, og den kinesiske udenrigsminister Tang Jiaxuan udtalte i 2002 i et interview til den japanske avis Mainichi Shimbun, at Kina nu ville anskue Japan ud fra et 'langsigtet og strategisk perspektiv', en strategi landet stadig følger.

I 2001 deltog Koizumi kort tid efter sin tiltrædelse officielt i en mindeceremoni ved Marco Polo broen i Kina, hvor Japan i 1937 lancerede sin storstilede invasion af landet, og lagde blomster ved dets monument. Forholdet mellem de to lande så ud til at være i bedring, indtil Koizumi påbegyndte sine Yasukuni besøg 
med den begrundelse, at efter Japans mange undskyldninger havde landet nu vundet retten til at ære sine egne faldne.

De diplomatiske forbindelser gik yderligere i hårdknude, da Koizumis efterfølger Shinzo Abe offentligt udtalte, at historierne om de titusindvis af koreanske kvinder, der var blevet tvunget i slaveri på bordeller for de japanske styrker, var vildt overdrevne, og løsnede først op igen, da Abe under hårdt pres fra omverdenen trak bemærkningerne tilbage. Efter Koizumis besøg ved Yasukuni og Abes uheldige kommentarer var lektien for alle tre parter: Lad kontroversen om krigen ligge - der står for meget andet på spil.

Ikke mindst fordi der ud over de handelsmæssige forbindelser også er strategiske interesser på spil i havene omkring de tre lande.

\section{Asiens vandveje}

Japan og Kina har sat hårdt mod hårdt $\mathrm{i}$ spillet $\mathrm{om}$ indflydelse over Asiens tre vigtigste vandveje, Malaccastrædet mellem Malaysia, Singapore og Indonesien, der er verdens travleste, det Sydkinesiske hav mellem Vietnam og Filippinerne og det Østkinesiske mellem Taiwan, Japan og Kina, ad hvilke søveje, der transporteres råvarer som den olie, der danner fundamentet for de tre landes økonomier. Under den kolde krig blev disse områder, som de stadig gør det i dag, sikret af den ame- rikanske flåde, men som Kinas økonomiske pondus er vokset, forsøger landet at få større og større kontrol på havet, og det bringer det på kollisionskurs ikke blot med USA, men også Japan.

Det falder sammen med, at Japan i takt med den kolde krigs afslutning er begyndt at se på sine egne maritime grænser som en vital del af den japanske stat - som da Yoichi Funabashi, en af Japans mest velrenommerede udenrigskommentatorer, pointerede i en kronik i avisen Asahi Shimbun, at da Japans havområder dækker over 4,47 millioner kvadratkilometer, var det kun naturligt, at Japan så på sig selv som en maritim magt. Derfor er der nu igen opstået spændinger mellem Japan og Korea over småøerne Takeshima i strædet mellem de to lande, som Japan officielt gør krav på, men som på nuværende tidspunkt er under sydkoreansk administration, og mellem Kina og Japan over Senkaku øerne, som Kina gør krav på.

En del af striden handler naturligvis om de ressourcer, der er at finde på havbunden omkring øerne, men for især Japan og Kinas vedkommende gælder det i overordnet strategisk betydning om at sikre sin tilstedeværelse i områder, hvis betydning vil vokse i de kommende år.

For Japan og Sydkorea er det også et udtryk for, at den japanske alliance med USA nu er gået ind i en ny fase, for selvom den amerikanske flådes tilstedeværelse i områderne 
stadig garanterer deres status som internationale farvande, kan Japan og Sydkorea nu ikke uden videre regne med, at USA ikke på sigt vil vige pladsen for Kina, efter at den kolde krigs relativt statiske internationale relationer er forsvundet.

Japan har reageret ved at flytte sit militære fokus på Rusland, så det i højere grad er vendt mod Kina. I 2004 flyttede det sine højtudviklede F-15C jagerfly til den sydlige $\varnothing$ Shimoji, kun 360 kilometer fra Taipei. Japans kystvagt er blevet udvidet med flere skibe, der næsten er på størrelse med destroyere, og i juli i år udgav et ekspertpanel en officiel rapport, der tilrådede, at det japanske forsvar gennemgik en serie radikale ændringer, der ville øge dets effektivitet. Japan har også samtidig med USA påbegyndt en lang serie diplomatiske og økonomiske forhandlinger med de sydøstasiatiske lande for også på den front at kunne dæmme op for den voksende kinesiske indflydelse i området.

Sydkoreas finansielle midler er mere beskedne og dets militær næsten udelukkende fokuseret på den nordkoreanske trussel - landet har derfor i over et årti forsøgt at gøre sig til bindeleddet i Østasiens handels- og transportnetværk, så det som Singapore kan øge sin indflydelse hos de større naboer ved at fungere som et vitalt omdrejningspunkt for deres økonomier.
Disse omstændigheder danner rammerne om de strategiske overvejelser, der nu finder sted i Tokyo, Seoul og Beijing, med et Østasien, hvor samarbejde og økonomisk integration skaber større tillid og stabilitet, mens det stille våbenkapløb mellem rivalerne Japan og Kina vokser i baggrunden, samtidig med at nationalismen ulmer hos alle tre.

Det er derfor heller ikke urimeligt at tro, at Anden Verdenskrigs tunge arv fortsat vil spille en prominent, om end mere nedtonet, rolle blandt de tre stolte nationer. Tilliden er på nuværende tidspunkt derfor også langt fra stor nok til, at de tre lande vil kunne finde sammen på et niveau som hos de europæiske nationer, mens et fortsat amerikansk overherredømme samtidig er uacceptabelt for Kina. Det politiske spil peger således frem mod en endnu ukendt magtbalance, som de tre lande nu er i færd med at manøvrere sig henimod så vidt muligt til egen fordel - en balance, hvor Kinas indflydelse kan holdes i ave gennem et regionalt net af handel og diplomati. Først da kan Japan og Sydkorea acceptere Kina som det naturlige centrum for et nyt Asien.

Thomas Høy Davidsen er journalist med speciale i Japan og østasiatiske forhold. Har oversat flere bøger fra japansk, og $i$ en årrakke skrevet for Weekendavisen. Skriver for The Economist. 